\title{
Resistance of Soybean Cultivars to Field Populations of Heterodera glycines in North Carolina
}

\author{
S. R. Koenning, Department of Plant Pathology, College of Agriculture and Life Sciences, North Carolina State \\ University, Raleigh 27695-7616
}

\begin{abstract}
Koenning, S. R. 2004. Resistance of soybean cultivars to field populations of Heterodera glycines in North Carolina. Plant Dis. 88:942-950.

The soybean cyst nematode (SCN), Heterodera glycines, is the most important pathogen of soybean, Glycine max, in North Carolina. Cultural practices are the most effective means of managing this pathogen because a majority of cultivars are susceptible to the races of this nematode that predominate in the state. Resistant and susceptible cultivars were evaluated in 14 H. glycines-infested fields from 1992 to 1999. Resistance in cvs. Hartwig and Delsoy 5710, and line S92-1603 derived from plant introduction (PI) 437654, was highly effective against all populations of $\mathrm{H}$. glycines evaluated in these experiments. Numbers of cysts (cysts and white females) per three plants 28 days after planting and final egg population densities (Pf) were lower than on other cultivars evaluated. Cultivars with SCN resistance derived from PI 90763 were moderately resistant in many of the test fields, but cultivars with Peking-derived resistance were effective at only two locations. Some cultivars with resistance derived from PI 88788 were highly to moderately resistant to races 9 or 14 of SCN, but were not consistently effective against other populations. Hartwig and Delsoy 5710 had low SCN reproductive factors $(\mathrm{Rf}=\mathrm{egg}$ density at harvest/mean egg density at planting for site) of 0.16 and 0.23 compared with an Rf of 1.9 and 2.19 on the susceptible cvs. Essex and Hutcheson, respectively. In contrast, the Rf on cultivars derived from Peking generally was greater than on susceptible cultivars. Resistant cvs. Hartwig and Delsoy 5710 generally yielded more than susceptible cultivars or cultivars derived from other sources of resistance. The initial inoculum level (Pi) was negatively correlated with soybean seed yield, but cysts 28 days after planting proved to be better at predicting seed yield than Pi. Due to the genetic diversity of $H$. glycines populations with regard to the ability to parasitize resistant cultivars, cultivars with resistance derived from PI 437654 or other genotypes are needed to manage this nematode in North Carolina.
\end{abstract}

Additional keywords: damage function, host-plant resistance

Worldwide, the most damaging pathogen of soybean (Glycine max L.) is the soybean cyst nematode (SCN), Heterodera glycines Ichinohe. This parasite is distributed throughout most soybean-growing areas in the United States, and infests a significant portion of the soybean hectarage in Brazil and Argentina (29). Significant soybean yield loss can occur in the absence of visual symptoms (28). Resistant cultivars and cultural practices are the primary means for alleviating yield losses

Corresponding author: S. R. Koenning

E-mail: stephen_koenning@ncsu.edu

This research was supported in part by the North Carolina State University College of Agriculture and Life Sciences Agricultural Research Service. The use of trade names does not imply an endorsement by the North Carolina Agricultural Research Service of the products named nor criticisms of similar ones not mentioned. Additional support was provided by the North Carolina Soybean Producers Association Inc.

Accepted for publication 28 April 2004.

Publication no. D-2004-0618-01R

(C) 2004 The American Phytopathological Society caused by this nematode $(6,8,11,14$ 18,24,34,35).

Cultural practices that may prevent soybean yield losses to $H$. glycines in North Carolina include rotation with nonhost crops, the use of early-maturing cultivars, planting date, and tillage method (14-18). Rotation is an effective means of managing $H$. glycines, especially when this practice is combined with other tactics $(16,18)$. Crop rotation, however, requires sufficient suitable land for nonhost crops that can be grown profitably. Inclusion of resistant cultivars in rotation sequences can shorten the interval needed between soybean crops grown in the cropping system.

Resistant cultivars can be cost-effective in management of $\operatorname{SCN}(8,12,14,19,34)$. The use of SCN-resistant cultivars, however, places selection pressure on populations of $H$. glycines that may result in changes in the frequency of alleles for parasitism on resistant cultivars (3033,35-37,39). This phenomenon has been referred to as a race shift for advisory purposes, and results in populations of $H$. glycines that can parasitize previously resistant cultivars $(37,39)$. Because of the genetic variability of this pathogen, peri- odic assessments of the ability of field populations to reproduce on resistant cultivars are required $(15,21,22)$. Spatial and temporal deployment of host-plant resistance genes to $H$. glycines have been proposed that may slow race shifts $(3,4,30-$ $33,37)$.

Selection of a resistant cultivar is complicated by several factors. The initial population density of SCN must exceed the damage threshold if a resistant cultivar, often with lower yield potential, is to be used. The race of SCN that is present in the field and the ability of a resistant cultivar to suppress nematode reproduction must be known. The initial race classification scheme for $H$. glycines was based on one resistant cultivar (Pickett) and three resistant plant introductions (PIs) and delineated four host races (20). Subsequently, the classification scheme was expanded to include 16 races, and a revised system of classification of $H$. glycines populations with regard to parasitism on a set of differentials has been proposed $(20,22)$. A female index (female index $[\mathrm{FI}]=$ number of females on a resistant cultivar/number of females on a susceptible cultivar $\times 100$ ) generally is used to describe the ability of a population to reproduce on a cultivar. Initially, cultivars were considered resistant if the FI for a race on a cultivar was less than $10 \%$ of that on a susceptible cultivar. A later proposal by Schmitt and Shannon (27) differentiates levels of resistance based on SCN reproduction or FI; with highly resistant (FI $<10)$, moderately resistant (FI $>10$ and <30) moderately susceptible (FI $>30$ and $<60$ ), and susceptible (FI $>60$ ) cultivars being delineated. The validity of this approach and its usefulness in SCN management, however, have not been evaluated. Typically, cultivars are considered to be highly resistant, moderately resistant, or susceptible.

Schmitt and Barker (25) found H. glycines in $33 \%$ of soybean fields in the North Carolina Coastal Plain sampled in 1985 and 1986. The populations at that time were categorized as race $1(18 \%)$, race 2 $(21 \%)$, race $3(15 \%)$, race $4(7 \%)$, race 5 $(16 \%)$, and others (23\%). A later survey conducted in North Carolina during the years 1994 to 1996 indicated that as much as $60 \%$ of the soybean hectarage may be infested with $H$. glycines, and that at least $56 \%$ of the populations of SCN could be categorized as either races 2 or 4 , with 
only $4 \%$ characterized as race 1 ; no populations of race 3 were found (15). Data from these surveys show that considerable variation occurs with respect to parasitism by this nematode on resistant cultivars, and that resistance to races 1 and 3 derived from Peking no longer would be effective in managing prevalent populations of $H$. glycines in many fields in the state.

Cv. Bedford, with resistance from both PI 88788 and Peking, was released as resistant to races 3 and 4 of SCN in 1977 (10). SCN populations that can reproduce on resistant cultivars derived from Peking but could not reproduce on Bedford now are generally considered to be either race 9 or 14 under the more recent 16-race system (22). Bedford was not used extensively in North Carolina (E. J. Dunphy, personal communication), but numerous cultivars with resistance derived from Bedford or its sister lines with resistance to races 3,9 , and 14 have gained acceptance in recent years. Still, these cultivars have only limited resistance to races 2 and 4, which predominate in North Carolina $(15,25)$. Cultivars with resistance to races 9 or 14 have resistance derived from PI 88788 , which also is susceptible to race 1 of $H$. glycines. Consequently, cultivars with resistance from sources other than Peking or PI 88788 would be useful in managing other races of $H$. glycines.

The only cultivars in maturity groups $\mathrm{V}$ or VI with resistance derived from sources other than Peking or PI 88788 are Cordell, TN5-92; Northrup King S61-89 (all with PI 90763 in their pedigree), Hartwig (Forrest $\times$ PI 437654), Delsoy 5710 (Hartwig $\times$ Hartz 5164), Anand, and Fowler (Hartwig $\times$ Holiday) $(1,2,5,9,10,15,38)$. Hartwig generally is considered resistant to all host races of $\mathrm{SCN}$ in the United States, although Young and other researchers have reported populations that can reproduce on Hartwig (36,37). Soybean cultivars derived from PI 90763 or PI 437654 have not been well received by growers because of poor agronomic performance and the difficulty in identifying fields where these types of resistance could be used efficiently. Cvs. Cordell, TN5-92, and Northrup King S61-89 are no longer available to growers. Hartwig has been replaced by Delsoy 5710, but neither cultivar has good yield potential. Cvs. Fowler and Anand were evaluated in the latter portion of this research and have better yield potential than Delsoy 5710, but these cultivars do not have the full compliment of resistance genes present in Delsoy $5710(1,2,5,38)$.

The effective use of resistant cultivars in cropping systems is dependent on two factors: (i) their ability to lower the population density of the nematode pathogen, and (ii) profitable yield in the presence of the nematode pathogen (23). The primary objective of this research was to evaluate the effectiveness of resistant soybean cultivars and lines in limiting reproduction of $H$. glycines field populations and determining their yield potential in infested fields in North Carolina.

\section{MATERIALS AND METHODS}

All experiments were conducted between 1992 and 1999 in fields naturally infested with the SCN (Table 1). Fields were in soybean-corn rotations prior to initiation of this study. Soybean breeders from various university experiment stations and private companies provided seed of soybean lines from maturity groups (MGs) V and VI with resistance to $\mathrm{SCN}$ each year (Table 2). Cvs. Essex (MG V), Hutcheson (MG V), Deltapine 105 (MG V), Young (MG VI), or Brim (MG VI) were susceptible controls. Cv. Centennial (MG VI) was used because it has resistance to races 1 and 3 of $\mathrm{SCN}$, and was useful in evaluating resistance derived solely from Peking.

Cultivars were arranged in a randomized complete block design with four to six replications at each location. There were two locations each year, with the exception of 1995. Cultivars differed between years, but all lines were included at both locations within a year. Results of experiments conducted in 1996 are not included because of severe hurricane damage to plots. Conventional tillage was used at all experimental sites. All plots consisted of four rows, $6.1 \mathrm{~m}$ long with $0.91-\mathrm{m}$ row spacing and $3.0-\mathrm{m}$ alleys between plots. The center two rows of each plot were harvested with a plot combine and seed yield was adjusted to $13 \%$ moisture.

Soil samples for assays of $H$. glycines eggs and cysts were collected at planting in May or June (mean preplant population density for the field [Pi]) and at soybean harvest in October (final egg density [Pf]). Each soil sample consisted of a composite of 8 to 102.5 -cm-diameter cores taken to a depth of $15 \mathrm{~cm}$. A $500-\mathrm{cm}^{3}$ subsample was processed by elutriation and centrifugation $(7,13)$. Eggs were extracted from cysts using a Ten-broeck homogenizer (Fisher Scientific, Pittsburgh, PA). Additional samples were taken by collecting three plants from each plot 28 days after planting (DAP) that were transported to the lab to count cysts and white females. Soil from these plants was removed gently by soaking in a bucket, and the number of cysts per three plants was determined in order to assess the level of resistance of each cultivar or line.

Reproductive factors (Rf) of $\mathrm{H}$. glycines were calculated for each cultivar by dividing Pf by $\mathrm{Pi}$. The mean and standard deviation for each cultivar across sites was calculated from the mean for each site. Similarly, mean yields for all locations in which the cultivar or line was included were calculated (Table 2) and relative yield was calculated by dividing the yield by the mean yield for each site. At sites where MG VI cultivars yielded significantly more $(P \leq 0.10)$ than MG V cultivars, the mean for the MG was used rather than the site mean.

Statistical analysis for individual sites used the PROC GLM procedure of

Table 1. Site designation, planting date, Heterodera glycines races, soil type, particle size distribution, initial population density (Pi) of $H$. glycines eggs plus juveniles per $500 \mathrm{~cm}^{3}$ of soil, and standard deviation (SD) of mean density

\begin{tabular}{|c|c|c|c|c|c|c|c|c|c|}
\hline \multirow[b]{2}{*}{ Site } & \multirow[b]{2}{*}{ Location } & \multirow[b]{2}{*}{ Planting date } & \multirow[b]{2}{*}{ Soil type } & \multirow[b]{2}{*}{ Sand $(\%)$} & \multirow[b]{2}{*}{ Silt (\%) } & \multirow[b]{2}{*}{ Clay $(\%)$} & \multicolumn{3}{|c|}{ Soybean cyst nematode } \\
\hline & & & & & & & Race $^{\mathbf{a}}$ & Mean Pi & SD \\
\hline 1 & Hoke & 20 May 1992 & Fuquay sand & 90 & 9 & 1 & 2 & 2,747 & 2,662 \\
\hline 2 & Robeson & 19 May 1992 & Norfolk sandy loam & 87 & 11 & 2 & 2 & 5,614 & 4,874 \\
\hline 3 & Pitt & 2 June 1993 & Goldsboro sandy loam & 83 & 14 & 3 & 2 & 803 & 956 \\
\hline 4 & Cumberland & 25 May 1993 & Fuquay sand & 89 & 10 & 1 & 2 & 26,827 & 37,162 \\
\hline 5 & Pasquotank & 18 May 1993 & Bayboro loam & 75 & 21 & 4 & 2 & 1,144 & 1,804 \\
\hline 6 & Tyrrel & 24 May 1994 & Weeksville sandy loam & 71 & 24 & 5 & 14 & 804 & 959 \\
\hline 7 & Martin & 26 May 1994 & Goldsboro fine sandy loam & 86 & 13 & 1 & 9 & 3,353 & 3,994 \\
\hline 8 & Washington & 24 May 1995 & Arapahoe fine sandy loam & 92 & 7 & 1 & 2 & 1,719 & 1,906 \\
\hline 9 & Johnston & 6 June 1997 & Norfolk sandy loam & 84 & 10 & 6 & 1 & 4,891 & 2,561 \\
\hline 10 & Washington & 28 May 1997 & Portsmouth fine sandy loam & 75 & 21 & 4 & 14 & 2,296 & 2,138 \\
\hline 11 & Chowan & 2 June 1998 & Tomotley fine sandy loam & 74 & 25 & 1 & 4 & 256 & 426 \\
\hline 12 & Washington & 1 June 1998 & Portsmouth fine sandy loam & 76 & 23 & 1 & 4 & 1,041 & 1,241 \\
\hline 13 & Wilson & 20 May 1999 & Norfolk sandy loam & 85 & 12 & 3 & 5 & 834 & 1,137 \\
\hline 14 & Currituck & 29 June 1999 & Roanoke fine sandy loam & 73 & 23 & 4 & 2 & 3,138 & 2,790 \\
\hline
\end{tabular}

a Race determined from a composite of preplant soil samples (22). 
Table 2. Cultivars or lines evaluated for resistance to Heterodera glycines (soybean cyst nematode [SCN]), company or university program, reported resistance to SCN races, source of resistance, maturity group (MG), sites tested (Table 1), resistance rating at specific site based on number of cysts 28 days after planting (DAP), mean and standard deviation (SD) of average reproductive factor (Rf) over sites tested from 1992 to 1999, average yield over all sites tested, and relative yield

\begin{tabular}{|c|c|c|c|c|c|c|c|c|c|c|c|}
\hline \multirow[b]{2}{*}{ Cultivar } & \multirow[b]{2}{*}{ Company $^{d}$} & \multirow[b]{2}{*}{ Resistance $^{\mathrm{e}}$} & \multirow[b]{2}{*}{ Source $^{f}$} & \multirow[b]{2}{*}{ MG } & \multirow[b]{2}{*}{ Sites tested } & \multicolumn{2}{|c|}{ Rating at site ${ }^{a}$} & \multicolumn{2}{|c|}{$\mathbf{R f ^ { \mathbf { b } }}$} & \multicolumn{2}{|c|}{ Yield $^{\mathrm{c}}$} \\
\hline & & & & & & HR & MR & Mean & SD & Mean (kg/ha) & Relative \\
\hline Hartwig & MO & $1-16$ & $\mathrm{Pk}, 437$ & V & $1-14$ & $1-14$ & $\ldots$ & 0.16 & 0.16 & 1,764 & 1.12 \\
\hline Delsoy 5500 & MO & 3,14 & $\mathrm{Pk}, 88$ & $\mathrm{~V}$ & 9,10 & $\ldots$ & $\ldots$ & 2.86 & 1.49 & 1,437 & 0.82 \\
\hline Delsoy 5710 & MO & $1-16$ & $\mathrm{Pk}, 437,88$ & $\mathrm{~V}$ & $9-14$ & $9-14$ & $\ldots$ & 0.23 & 0.36 & 1,875 & 1.05 \\
\hline Anand & MO & $1,2,3,5,14$ & $\mathrm{Pk}, 437$ & V & 11,12 & 11 & $\ldots$ & 2.24 & 2.63 & 2,303 & 1.00 \\
\hline Fowler & $\mathrm{TN}$ & $1,2,3,5,14$ & $\mathrm{Pk}, 437$ & V & $11-14$ & $11,13,14$ & 12 & 1.90 & 3.68 & 2,365 & 1.29 \\
\hline S84-1876 & MO & 3,14 & $\mathrm{Pk}, 88$ & V & $1-5$ & $\ldots$ & 1 & 1.89 & 2.54 & 751 & 0.94 \\
\hline S92-1603 & MO & $1-6$ & $\mathrm{Pk}, 437$ & VI & 8 & 8 & $\ldots$ & 0.19 & $\ldots$ & 2,828 & 1.10 \\
\hline Cordell & $\mathrm{TN}$ & $1,3,5(\mathrm{MR} 2,14)$ & $\mathrm{Pk}, 88,90$ & $\mathrm{~V}$ & $3-7$ & $\ldots$ & $3,5,7$ & 2.13 & 3.38 & 1,604 & 0.94 \\
\hline TN 5-92 & $\mathrm{TN}$ & $1,3,5(\mathrm{MR} 2,14)$ & $\mathrm{Pk}, 88,90$ & $\mathrm{~V}$ & $3-12$ & 9,10 & $3,4,7,8,12$ & 2.12 & 3.22 & 1,890 & 1.00 \\
\hline TN 5-95 & $\mathrm{TN}$ & 3,14 & $\mathrm{Pk}, 88$ & $\mathrm{~V}$ & $8-14$ & $\ldots$ & 9 & 2.10 & 2.15 & 1,823 & 0.95 \\
\hline A5979 & Asgrow & 3,4 & $\mathrm{Pk}, 88$ & $\mathrm{~V}$ & $1-8$ & 6 & 1 & 1.84 & 0.90 & 1,481 & 0.93 \\
\hline A5843 & Asgrow & 3,14 & $\mathrm{Pk}, 88$ & $\mathrm{~V}$ & $6-14$ & $6,10,11$ & $\ldots$ & 2.48 & 3.09 & 2,004 & 1.01 \\
\hline A5848 & Asgrow & $1,3,14(\mathrm{MR} 2)$ & $\mathrm{Pk}, 88$ & $\mathrm{~V}$ & $9-14$ & 10,11 & 12 & 1.99 & 2.00 & 1,917 & 1.07 \\
\hline A5545 & Asgrow & 3 & $\mathrm{Pk}$ & $\mathrm{V}$ & 6,7 & $\ldots$ & 6 & 1.03 & 0.04 & 1,935 & 0.88 \\
\hline A5547 & Asgrow & 3,14 & $\mathrm{Pk}, 88$ & $\mathrm{~V}$ & $8-10$ & 10 & $\ldots$ & 1.47 & 0.85 & 2,086 & 1.04 \\
\hline Dp 415 & Deltapine & 1,3 & $\mathrm{Pk}$ & $\mathrm{V}$ & $1-5$ & $\ldots$ & $\ldots$ & 1.62 & 0.75 & 843 & 0.76 \\
\hline Dp 3519 & Deltapine & $3,9,14$ & $\mathrm{Pk}, 88$ & $\mathrm{~V}$ & $8-14$ & $\ldots$ & 9,10 & 2.87 & 3.58 & 1,869 & 0.95 \\
\hline Dp 3571 & Deltapine & 3,14 & $\mathrm{Pk}, 88$ & $\mathrm{~V}$ & 8 & $\ldots$ & $\ldots$ & 1.57 & $\ldots$ & 2,739 & 1.06 \\
\hline Dp 3588 & Deltapine & 3 & $\mathrm{Pk}, 88$ & $\mathrm{~V}$ & 9,10 & $\ldots$ & 9 & 4.47 & 5.00 & 1,790 & 1.03 \\
\hline Dp 5354 & Deltapine & 3 & 88 & $\mathrm{~V}$ & 11,12 & $\ldots$ & 11 & 5.35 & 6.57 & 2,061 & 0.90 \\
\hline DPX4090 & Deltapine & ND & NA & $\mathrm{V}$ & $3-5$ & $\ldots$ & $\ldots$ & 1.18 & 0.63 & 1,169 & 0.74 \\
\hline H5164 & Hartz & $3,9,14$ & $\mathrm{Pk}, 88$ & $\mathrm{~V}$ & $1-8$ & $\ldots$ & 1,6 & 1.84 & 0.97 & 1,459 & 0.95 \\
\hline H5164RR & Hartz & $3,9,14$ & $\mathrm{Pk}, 88$ & V & 9,10 & $\ldots$ & 9,10 & 3.29 & 3.90 & 1,749 & 1.01 \\
\hline Н5566 & Hartz & $3,9,14$ & $\mathrm{Pk}, 88$ & V & $6-8$ & $\ldots$ & 6 & 3.05 & 1.27 & 2,237 & 1.02 \\
\hline Hartz 5350 & Hartz & 3,14 & 88 & $\mathrm{~V}$ & $8-10$ & $\ldots$ & 9,10 & 2.06 & 1.99 & 1,807 & 0.86 \\
\hline S57-11 & Syngenta & 3 (MR 14) & $\mathrm{Pk}, 88$ & V & $6,7,9-14$ & 6 & 7,10 & 2.28 & 2.26 & 1,890 & 1.00 \\
\hline S59-95 & Syngenta & 3,4 & $\mathrm{Pk}, 88$ & $\mathrm{~V}$ & 8 & $\ldots$ & $\ldots$ & 2.97 & $\ldots$ & 2,951 & 1.14 \\
\hline S57-A4 & Syngenta & $3,9,14$ & 88 & $\mathrm{~V}$ & 13,14 & $\ldots$ & $\ldots$ & 1.70 & 1.78 & 1,334 & 1.00 \\
\hline x9851 & Syngenta & ND & NA & $\mathrm{V}$ & 11,12 & $\ldots$ & 12 & 6.74 & 9.44 & 2,399 & 1.07 \\
\hline x9855 & Syngenta & ND & NA & V & 11,12 & $\ldots$ & $\ldots$ & 6.47 & 7.97 & 2,297 & 0.99 \\
\hline x 9955 & Syngenta & ND & NA & V & 13,14 & $\ldots$ & $\ldots$ & 1.43 & 1.08 & 1,296 & 0.96 \\
\hline 9521 & Pioneer & 3,14 & NA & $\mathrm{V}$ & $3-5$ & $\ldots$ & $\ldots$ & 0.66 & 0.30 & 1,247 & 0.80 \\
\hline $96 \mathrm{~B} 01$ & Pioneer & 3,14 & $\mathrm{Pk}, 88$ & VI & 13,14 & $\ldots$ & $\ldots$ & 0.99 & 0.87 & 1,335 & 0.95 \\
\hline Robin 5 & Riverside & $3,5,9$ & NA & $\mathrm{V}$ & 11,12 & $\ldots$ & $\ldots$ & 10.07 & 13.02 & 1,978 & 0.84 \\
\hline Essex & VA & $\mathrm{S}$ & $\ldots$ & V & $1-7$ & $\ldots$ & $\ldots$ & 1.90 & 1.74 & 924 & 0.67 \\
\hline Hutcheson & VA & $\mathrm{S}$ & $\ldots$ & V & $3-14$ & $\ldots$ & $\ldots$ & 2.19 & 1.58 & 1,518 & 0.83 \\
\hline DP105 & Deltapine & $\mathrm{S}$ & $\ldots$ & $\mathrm{V}$ & $1-7$ & $\ldots$ & $\ldots$ & 2.64 & 2.27 & 1,317 & 0.98 \\
\hline DP566 & Deltapine & $\mathrm{S}$ & $\ldots$ & VI & 1,2 & $\ldots$ & $\ldots$ & 2.30 & 1.66 & 388 & 0.71 \\
\hline Centennial & $\mathrm{TN}$ & 1,3 & $\mathrm{Pk}$ & VI & $1-14$ & 9 & $\ldots$ & 5.47 & 6.28 & 1,668 & 0.91 \\
\hline NC 93-54 & $\mathrm{NC}$ & 3,14 & $\mathrm{Pk}, 88$ & $\mathrm{~V}$ & 11,12 & $\ldots$ & 11 & 4.26 & 5.76 & 2,185 & 0.96 \\
\hline NC 96-223 & $\mathrm{NC}$ & 3,14 & $\mathrm{Pk}, 88$ & $\mathrm{~V}$ & 13,14 & 13 & $\ldots$ & 0.73 & 0.89 & 1,283 & 0.92 \\
\hline A6711 & Asgrow & 3 & $\mathrm{Pk}$ & VI & 6,7 & $\ldots$ & $\ldots$ & 5.17 & 4.30 & 2,363 & 1.09 \\
\hline DP726 & Deltapine & 1,3 & $\mathrm{Pk}$ & VI & 8 & $\ldots$ & $\ldots$ & 3.03 & $\ldots$ & 2,380 & 0.92 \\
\hline DP6200RR & Deltapine & 3 (MR 14) & $\mathrm{Pk}, 88$ & VI & $11-14$ & $\ldots$ & $\ldots$ & 9.44 & 15.13 & 1,897 & 1.03 \\
\hline DP3640 & Deltapine & 3,9 (MR 14) & $\mathrm{Pk}, 88$ & VI & $9-14$ & 9 & 14 & 7.02 & 11.98 & 2,064 & 1.10 \\
\hline DP3681 & Deltapine & 1,3 & $\mathrm{Pk}$ & VI & $9-12$ & $\ldots$ & 9,10 & 11.15 & 15.83 & 2,228 & 1.01 \\
\hline DPX6-4821 & Deltapine & ND & NA & VI & 8 & $\ldots$ & $\ldots$ & 4.97 & $\ldots$ & 2,665 & 1.03 \\
\hline Н 6104 & Hartz & 3 & $\mathrm{Pk}$ & VI & 9,10 & 9 & 10 & 2.38 & 3.30 & 2,415 & 1.15 \\
\hline HX 613219 & Hartz & ND & NA & VI & 6,7 & $\ldots$ & $\ldots$ & 5.24 & 5.34 & 2,002 & 0.92 \\
\hline HX 615389 & Hartz & ND & NA & VI & 8 & $\ldots$ & $\ldots$ & 2.34 & $\ldots$ & 2,787 & 1.08 \\
\hline S61-89 & Syngenta & $3,4,5$ & $\mathrm{Pk}, 90$ & VI & $1-8$ & $\ldots$ & 1,4 & 1.85 & 0.90 & 1,609 & 0.91 \\
\hline S62-62 & Syngenta & 3,4 & $\mathrm{Pk}, 88$ & VI & 9,10 & 10 & $\ldots$ & 2.00 & 1.83 & 1,596 & 0.79 \\
\hline S62-66 & Syngenta & 3,4 & $\mathrm{Pk}, 88$ & VI & $1-8$ & 1,6 & 4,7 & 1.99 & 1.17 & 1,546 & 0.99 \\
\hline S66-90 & Syngenta & 3,4 & $\mathrm{Pk}, 88$ & VI & $6-8$ & $\ldots$ & 6 & 1.90 & 0.20 & 2,395 & 1.01 \\
\hline S65-50 & Syngenta & 3,9 (MR 14) & $\mathrm{Pk}, 88$ & VI & $9-14$ & $\ldots$ & $10,11,12$ & 4.40 & 5.39 & 2,085 & 1.08 \\
\hline S60-E4 & Syngenta & 3,14 & $\mathrm{Pk}, 88$ & VI & 9,10 & $\ldots$ & 10 & 2.99 & 2.82 & 1,817 & 0.89 \\
\hline Brim & $\mathrm{NC}$ & $\mathrm{S}$ & $\ldots$ & VI & $3-7$ & $\ldots$ & $\ldots$ & 3.47 & 2.35 & 1,856 & 0.93 \\
\hline Young & $\mathrm{NC}$ & $\mathrm{S}$ & $\ldots$ & VI & $1-14$ & $\ldots$ & $\ldots$ & 3.37 & 3.49 & 1,695 & 0.99 \\
\hline
\end{tabular}

${ }^{a}$ Resistance rating is based on (number of cysts on roots of three plants $28 \mathrm{DA} /$ number of cysts on susceptible cultivars 28 DAP) $\times 100$. Highly resistant (HR) is defined as $<10$ and moderately resistant (MR) as $>10$ and $<30$ (27).

b Reproductive factor $(\mathrm{Rf})=$ mean egg density at harvest/mean preplant density for site.

${ }^{c}$ Mean yields for all locations in which the cultivar or line was included, and relative yield was calculated by dividing the yield by the mean yield for each site. At sites where MG VI cultivars yielded more $(P \leq 0.10)$ than MG V cultivars, the mean for the MG was used rather than the site mean.

${ }^{\mathrm{d}} \mathrm{MO}=$ University of Missouri Agricultural Experiment Station, NC = North Carolina Agricultural Experiment Station, TN = University of Tennessee Agricultural Experiment Station, VA = Virginia Polytechnical Agricultural Experiment Station. Syngenta is used for companies formerly known as Novartis, and Northrup King.

e Specific resistance to races of $H$. glycines as reported by companies, soybean breeders, or university experiment stations (10). Cultivars listed as resistant to races 3 and 4 are likely resistant to races 3,9 , or 14 according to a later classification system (22). ND indicates not determined and S indicates susceptible.

f Resistance source: $\mathrm{Pk}=$ Peking, $88=$ plant introduction $(\mathrm{PI}) 88788,90=\mathrm{PI} 90763,437=\mathrm{PI} 437654$, and NA = not available. 
PC/SAS software (SAS Institute, Cary, $\mathrm{NC)}$ for a randomized complete block design for each year and location, because locations and years differed (Table 3). Orthogonal contrasts were used to evaluate the effects of MG. Based on 28-DAP samples (cysts and white females), cultivars were considered to be highly resistant if the number of cysts on a cultivar was less than $10 \%$ of the mean on susceptible cultivars, moderately resistant if the number of cysts was $>10 \%$ but $<30 \%$ of those found on susceptible cultivars, and susceptible if the number of cysts was $>30 \%$ (27). Orthogonal contrasts were used to separate differences between highly resistant, moderately resistant, and susceptible cultivars. Nematode numbers were transformed $\left(\log _{10}[x+1]\right)$ to normalize variances. Untransformed data are presented in tables for clarity. Regression models were developed using the PROC MIXED procedure of PC/SAS with year and location nested in year as random variables. A stepwise procedure eliminating terms that were not significant $(P \leq 0.05)$ was used to simplify the model and discriminate between quadratic versus linear models. Approximate 99\% confidence limits were estimated from this procedure.

\section{RESULTS}

Analyses across all locations. Reproductive factors on cultivars or lines derived from PI 437654 (Hartwig, Delsoy 5710, and S92-1603) were 0.16, 0.23, and 0.19, respectively (Table 2). In comparison, the average $\mathrm{Rf}$ for susceptible MG V cvs. Essex, Hutcheson, and DP 105 were 1.90, 2.19 , and 2.64 , respectively, or approximately 10-fold greater. Susceptible MG VI cultivars generally had greater Rf values than susceptible MG V cultivars (Table 3). Population densities of $H$. glycines generally were higher at soybean harvest than at soybean planting on susceptible cultivars or lines at most locations (Table 4). Final population densities did not increase over

Table 3. Partial analysis of variance main effects on mean values for each soybean cultivar or line at a location in experiments performed in 1992 to 1999

\begin{tabular}{lcccc}
\hline & & & \multicolumn{2}{c}{$\boldsymbol{F}_{\text {value }}$} \\
\cline { 3 - 5 } Source & DF & Rf $^{\mathbf{b}}$ & $\mathbf{P f}^{\mathbf{b}}$ & Yield \\
\hline Year & 6 & $17.71^{* *}$ & $29.02^{* *}$ & $171.95^{* *}$ \\
Location (year) & 7 & $33.95^{* *}$ & $15.80^{* *}$ & $71.21^{* *}$ \\
Maturity group & 1 & $19.70^{* *}$ & $52.0^{* *}$ & $17.33^{* *}$ \\
Pi & 1 & 0.58 & 0.14 & 1.49 \\
Cysts 28 DAP & 1 & $19.70^{* *}$ & $255.37^{* *}$ & $39.82^{* *}$ \\
\hline
\end{tabular}

a Values followed by $* *$ are significant at $P \leq 0.01$. Rf is the reproductive factor $(\mathrm{Rf}=$ mean egg density at harvest/initial inoculum level for site), Pf is the final egg population density per $500 \mathrm{~cm}^{3}$ of soil, and yield is soybean seed yield ( $\mathrm{kg} / \mathrm{ha})$.

${ }^{\mathrm{b}}$ Analysis performed on transformed values $\left(\log _{10} X+1\right)$.

${ }^{\mathrm{c}} \mathrm{DAP}=$ days after planting initial populations on susceptible cultivars at the Robeson County site in 1992 and the Cumberland County site in 1993, because of extensive damage to soybean due to high initial population density, resulting in severe stunting of soybean (Tables 1 and 4). Final SCN population development also was limited at three sites (Pasquotank County in 1993 and Currituck and Wilson counties in 1999) because of saturated soils in the latter portions of the growing season. A linear model best described the relationship $(P \leq 0.0001)$ between the number of cysts on a cultivar 28 DAP with $H$. glycines Rf, but a quadratic model adequately $(P \leq 0.0001)$ described the relationship between cysts $28 \mathrm{DAP}$ and the final egg population density/500 $\mathrm{cm}^{3}$ of soil (Figs. 1 and 2).

Highly resistant cultivars yielded more $(P$ $\leq 0.10$ ) than susceptible cultivars at $64 \%$ of the sites evaluated, and moderately resistant cultivars yielded more $(P \leq 0.10)$ than susceptible cultivars at $36 \%$ of the locations. MG VI cultivars yielded more $(P \leq 0.10)$ than MG V cultivars at 7 of the 14 sites (Table 5). MG V cultivars out yielded MG VI soybean cultivars only at the Currituck location in 1999. Soybean seed yield was related $(P \leq 0.0001)$ to the number of cysts per three plants 28 DAP by a linear relationship (Fig. 3). Although preliminary analysis indicated that the pre-plant number of $H$. glycines eggs $/ 500 \mathrm{~cm}^{3}$ of soil was negatively related to soybean yield, further analysis with PROC MIXED of SAS with locations and years as random factors showed that $\mathrm{Pi}$ was not a significant factor in determining yield when the variable cysts 28 DAP was included in the model (Table 3 ).

Table 4. Number of cultivars per resistance class (resistance class based on cysts 28 days after planting [DAP]), population densities of Heterodera glycines, mean number of cysts per three plants 28 DAP, number of eggs per $500 \mathrm{~cm}^{3}$ of soil at soybean harvest (Pf), and orthogonal contrasts (OC) for comparisons at 28 DAP, based on resistance class at 14 sites from 1992 to 1995 and 1997 to 1999 in North Carolina

\begin{tabular}{|c|c|c|c|c|c|c|c|c|c|c|c|c|c|c|c|c|}
\hline \multirow[b]{3}{*}{ Year, site } & \multirow[b]{3}{*}{ County } & \multirow{2}{*}{\multicolumn{3}{|c|}{ Class $^{\mathrm{a}}$}} & \multirow{2}{*}{\multicolumn{3}{|c|}{ Mean no. cysts }} & \multirow{2}{*}{\multicolumn{3}{|c|}{$\begin{array}{c}P \text { value } \\
\text { OC for cysts }\end{array}$}} & \multirow{2}{*}{\multicolumn{3}{|c|}{ Mean Pf for class }} & \multirow{2}{*}{\multicolumn{3}{|c|}{$\begin{array}{c}P \text { value } \\
\mathrm{OC} \text { for } \mathrm{Pf}\end{array}$}} \\
\hline & & & & & & & & & & & & & & & & \\
\hline & & HR & MR & $\mathbf{S}$ & HR & MR & $\mathbf{S}$ & HR vs MR & HR vsS & MR vsS & HR & MR & $\mathbf{S}$ & HRw M & HR vs $S$ & MR vs $S$ \\
\hline \multicolumn{17}{|l|}{1992} \\
\hline 1 & Hoke & 2 & 4 & 6 & 20 & 53 & 238 & 0.01 & 0.01 & 0.01 & 3,066 & 3,008 & 8,005 & 0.84 & 0.01 & 0.01 \\
\hline 2 & Robeson & 1 & 0 & 11 & 6 & $\ldots$ & 419 & $\ldots$ & 0.01 & $\ldots$ & 900 & $\ldots$ & 4,796 & $\ldots$ & 0.01 & $\ldots$ \\
\hline \multicolumn{17}{|l|}{1993} \\
\hline 3 & Pitt & 1 & 2 & 14 & 7 & 14 & 75 & 0.62 & 0.02 & 0.06 & 433 & 4,883 & 6,002 & 0.92 & 0.03 & 0.54 \\
\hline 4 & Cumberland & 1 & 4 & 12 & 0 & 24 & 102 & 0.51 & 0.01 & 0.01 & 2,733 & 9,825 & 12,623 & 0.10 & 0.01 & 0.08 \\
\hline 5 & Pasquotank & 1 & 1 & 15 & 0 & 1 & 9 & 0.12 & 0.15 & 0.45 & 200 & 66 & 1,481 & 0.86 & 0.09 & 0.04 \\
\hline \multicolumn{17}{|l|}{1994} \\
\hline 6 & Tyrrel & 5 & 5 & 10 & 8 & 34 & 106 & 0.09 & 0.01 & 0.01 & 1,250 & 3,550 & 4,993 & 0.03 & 0.01 & 0.11 \\
\hline 7 & Martin & 1 & 4 & 15 & 2.0 & 20 & 68 & 0.60 & 0.01 & 0.04 & 200 & 4,633 & 6,345 & 0.05 & 0.01 & 0.13 \\
\hline \multicolumn{17}{|l|}{1995} \\
\hline \multicolumn{17}{|l|}{1997} \\
\hline 9 & Johnston & 6 & 7 & 9 & 0.41 & 8.3 & 21 & 0.04 & 0.01 & 0.01 & 483 & 3,328 & 6,342 & 0.01 & 0.01 & 0.01 \\
\hline 10 & Washington & 7 & 10 & 5 & 1.97 & 14.9 & 50.4 & 0.02 & 0.01 & 0.01 & 3,242 & 8,123 & 8,520 & 0.01 & 0.01 & 0.71 \\
\hline \multicolumn{17}{|l|}{1998} \\
\hline 11 & Chowan & 4 & 6 & 12 & 1.50 & 6.5 & 23.7 & 0.01 & 0.01 & 0.01 & 812 & 2,593 & 4,861 & 0.01 & 0.01 & 0.03 \\
\hline 12 & Washington & 2 & 4 & 16 & 3.0 & 17.2 & 59.2 & 0.38 & 0.01 & 0.01 & 276 & 1,406 & 1,120 & 0.02 & 0.05 & 0.35 \\
\hline \multicolumn{17}{|l|}{1999} \\
\hline 13 & Wilson & 4 & 4 & 10 & 1.4 & 22.4 & 75.0 & 0.01 & 0.01 & 0.22 & 319 & 1,320 & 1,875 & 0.01 & 0.01 & 0.22 \\
\hline 14 & Currituck & 3 & 0 & 15 & 0.23 & $\ldots$ & 53.7 & $\ldots$ & 0.01 & $\ldots$ & 33 & $\ldots$ & 1,211 & $\ldots$ & 0.01 & $\ldots$ \\
\hline
\end{tabular}

${ }^{a}$ Number of cultivars in class. Density classes are based on cyst numbers at 28 DAP; resistance rating is based on (number of cysts on roots of plants 28 $\mathrm{DAP} /$ number of cysts on susceptible cultivars $28 \mathrm{DAP}) \times 100$. Highly resistant $(\mathrm{HR})$ is defined as $<10$ and moderately resistant as $>10$ and $<30(27)$. 
Reproduction of $\mathrm{H}$. glycines and impact on soybean yield in Hoke and Robeson counties, 1992. Cvs. Hartwig and S62-66 were highly resistant at the Hoke County site, whereas four cultivars were moderately resistant at this location (A5979, S84-1876, H5164, and S61-89), based on samples taken 28 DAP. Highly resistant cultivars differed from moderately resistant cultivars in numbers of cysts at 28 DAP, and moderately resistant cultivars differed from susceptible cultivars $(P \leq$ 0.01; Table 4). Highly resistant and moderately resistant cultivars had lower numbers of $H$. glycines eggs at soybean harvest at this location $(P \leq 0.01)$, but highly resistant cultivars did not have lower egg population densities than moderately resistant cultivars. Soybean seed yield of highly resistant (Hartwig and S62-66), and moderately resistant (A5979, S84-1876, H5164, and S61-89) cultivars were greater $(P \leq 0.10)$ than susceptible cultivars at the Hoke County location. Yields of highly resistant and moderately resistant cultivars did not differ at this location.

The only cultivar resistant to the race 4 population at the Robeson County site was Hartwig, which had lower numbers of cysts 28 DAP, and a lower $(P \leq 0.01)$ final
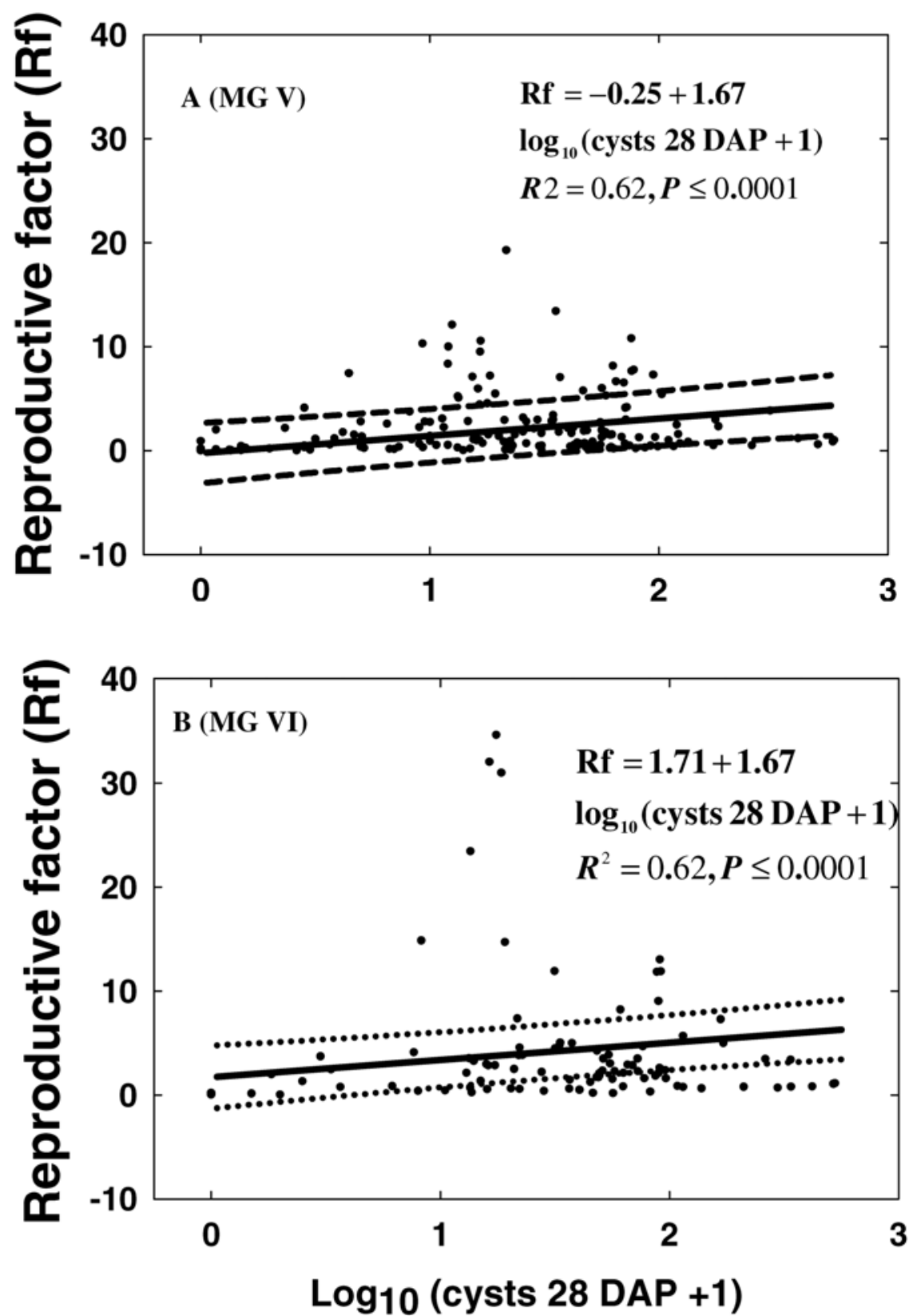

Fig. 1. Relationship of the reproductive factor $(\mathrm{Rf}=$ mean egg density at harvest $/$ mean preplant density for site) to the number of Heterodera glycines cysts per three plants at 28 days after planting (DAP). Each data point is the mean of six observations per cultivar at each location from 1992 to 1999. Solid line is predicted response and dotted lines are the approximate $99 \%$ confidence intervals from the PROC MIXED procedure of SAS. Responses differed $(P \leq 0.0001)$ by maturity group $(\mathrm{MG})$; thus, data are reported separately for $\mathbf{A}, \mathrm{MG} \mathrm{V}$ and $\mathbf{B}, \mathrm{MG}$ VI. $R^{2}$ value is for regression analysis, including both MGs as qualitative variables.

population density than the mean for all other cultivars evaluated. Centennial and DP 415 with resistance to $\mathrm{SCN}$ races 1 and 3 did not have lower numbers of cysts 28 DAP or final population density than susceptible cultivars (data not included). Hartwig, the only resistant cultivar at this location, yielded more than susceptible cultivars $(P \leq 0.10)$.

Reproduction of $\mathrm{H}$. glycines and impact on soybean yield in Cumberland, Pasquotank, and Pitt counties, 1993. Only Hartwig was highly resistant to the race 2 populations of SCN present at the three locations used in 1993. Hartwig differed $(P \leq 0.02)$ in numbers of cysts 28 DAP from susceptible cultivars at both the Cumberland and Pitt County sites. Cyst numbers at 28 DAP for moderately resistant cultivars were not different from Hartwig at the Cumberland or Pitt sites, but cyst numbers for both highly and moderately resistant cultivars were lower than on susceptible cultivars at theses locations ( $P$ $\leq$ 0.10). Cultivars S61-89, S62-62, Cordell, and TN5-92 were moderately resistant to $\mathrm{SCN}$ at the Cumberland County site, but only Cordell and TN5-92 were moderately resistant at the Pitt County site. TN5-92 was moderately resistant compared with susceptible cultivars at the Pasquotank County site in 1993. Highly resistant cv. Hartwig was effective in limiting the final population density of $H$. glycines eggs at all three locations $(P \leq 0.10)$ compared with susceptible cultivars. Moderately resistant cultivars had lower $(P \leq 0.10)$ levels of SCN eggs at harvest than susceptible cultivars at the Pitt and Cumberland County sites, but not at the Pasquotank County site. The lack of difference between final population densities at the Pasquotank County site is probably because of generally low $H$. glycines reproduction at this location, possibly a result of excessive rainfall.

Highly and moderately resistant cultivars yielded more $(P \leq 0.01)$ than susceptible cultivars at the Cumberland County location, but moderately and highly resistant cultivars did not differ in yield $(P \leq$ 0.10). Moderately resistant cvs. Cordell and TN5-92 had greater yields than highly resistant cv. Hartwig or the susceptible cultivars $(P \leq 0.07$ and 0.05 , respectively) at the Pitt County site, and cultivars did not differ with respect to soybean yield at the Pasquotank County site.

Reproduction of $\mathrm{H}$. glycines and impact on soybean yield in Martin and Tyrell counties 1994. Hartwig, A5979, A5843, S57-11, and S62-66 all were highly resistant to the $\mathrm{SCN}$ race 14 population at the Tyrell County site compared with susceptible cultivars. Five cultivars (A5545, H5164, H5566, S66-90, and S61-89) were moderately resistant, and had lower $(P \leq 0.01)$ numbers of cysts 28 DAP than susceptible cultivars. The number of cysts 28 DAP was lower $(P \leq 0.09)$ 
on highly resistant than on moderately resistant cultivars at the Tyrrell County location, and highly resistant cultivars had lower end-of-season egg densities than either moderately resistant or susceptible cultivars $(P \leq 0.03$ and 0.01 , respectively) at the end of the season. Final population densities did not differ between moderately resistant and susceptible cultivars. Highly and moderately resistant cultivars yielded more $(P \leq 0.01)$ than susceptible cultivars, and highly resistant cultivars yielded more than moderately resistant cultivars $(P \leq$ $0.04)$ at the Tyrell County site. MG did not influence yield at this location.

Only Hartwig was highly resistant to the race $9 \mathrm{SCN}$ population at the Martin County site, whereas five cultivars (A5979, Cordell, TN5-92, N57-11, and S62-66) were moderately resistant. Moderately resistant cultivars did not differ from Hartwig in numbers of cysts 28 DAP, and final egg density of $H$. glycines on the highly resistant Hartwig was less than on moderately resistant or susceptible cultivars ( $P \leq 0.05$ and 0.01 , respectively). Moderately resistant cultivars did not differ from susceptible cultivars at the Martin County location for Pf. Hartwig yielded more $(P \leq 0.01)$ than either moderately resistant cultivars or susceptible cultivars at the Martin County site. Yield of moderately resistant and susceptible cultivars did not differ $(P \leq 0.10)$ because four of the five moderately resistant cultivars were in MG V, and MG VI cultivars yielded more $(P \leq 0.01)$ than MG V cultivars in the Martin County experiment.

Reproduction of $\mathrm{H}$. glycines and impact on soybean yield in Washington County, 1995. One experimental site in 1995 located in Washington County, NC, was infested with race 2 of $H$. glycines. $\mathrm{Cv}$. Hartwig and line S92-1603 were highly resistant, and TN5-92 was moderately resistant to this population. The number of cysts 28 DAP was greater $(P \leq$ 0.01 and 0.03 ) on susceptible cultivars than on either highly or moderately resistant cultivars or lines, respectively, but differences between highly and moderately resistant cultivars $(P=0.10)$ were not observed. Hartwig and S92-1603 had lower $(P=0.05) H$. glycines reproduction at season's end than susceptible cultivars, but SCN reproduction on the moderately resistant TN5-92 did not differ from that on susceptible cultivars. Yields of highly or moderately resistant cultivars did not differ $(P \leq 0.10)$ from susceptible cultivars, because $\mathrm{MG}$ VI cultivars, all of which were susceptible, yielded more at this location.

Reproduction of $\mathrm{H}$. glycines and impact on soybean yield in Johnston and Washington counties, 1997. The population at the Johnston County site was classified as $H$. glycines race 1 . Cultivars that were highly resistant to this population included Hartwig, Delsoy 5710, TN5-92,
H6104, H5164RR, and DP 3640 based on 28 DAP cyst numbers. Seven cultivars (DP 3519, DP 3588, DP 3681, H5164RR, H5350, S62-62, and TN5-95) were moderately resistant to SCN race 1 at this location. Highly resistant, moderately resistant, and susceptible cultivars differed $(P \leq$ 0.04 ) in numbers of cysts $28 \mathrm{DAP}$ and final population density of nematodes $(P \leq$ more $(P \leq 0.01)$ than moderately resistant or susceptible cultivars, but the yield of moderately resistant cultivars did not differ $0.01)$. Highly resistant cultivars yielded

from susceptible cultivars. The higher $(P \leq$ 0.01 ) yield of MG VI compared with MG $\mathrm{V}$ cultivars accounts for the lack of difference between susceptible cultivars and moderately resistant cultivars because five of the seven moderately resistant cultivars were in MG V.

Hartwig, Delsoy 5710, A5843, A5848, A5547, S62-62, and TN5-92 were highly resistant to $H$. glycines race 14 at the Washington County site. Moderately resistant cultivars included Delsoy 5500, DP 3519, DP 3681, H6104, H5164, H5350,
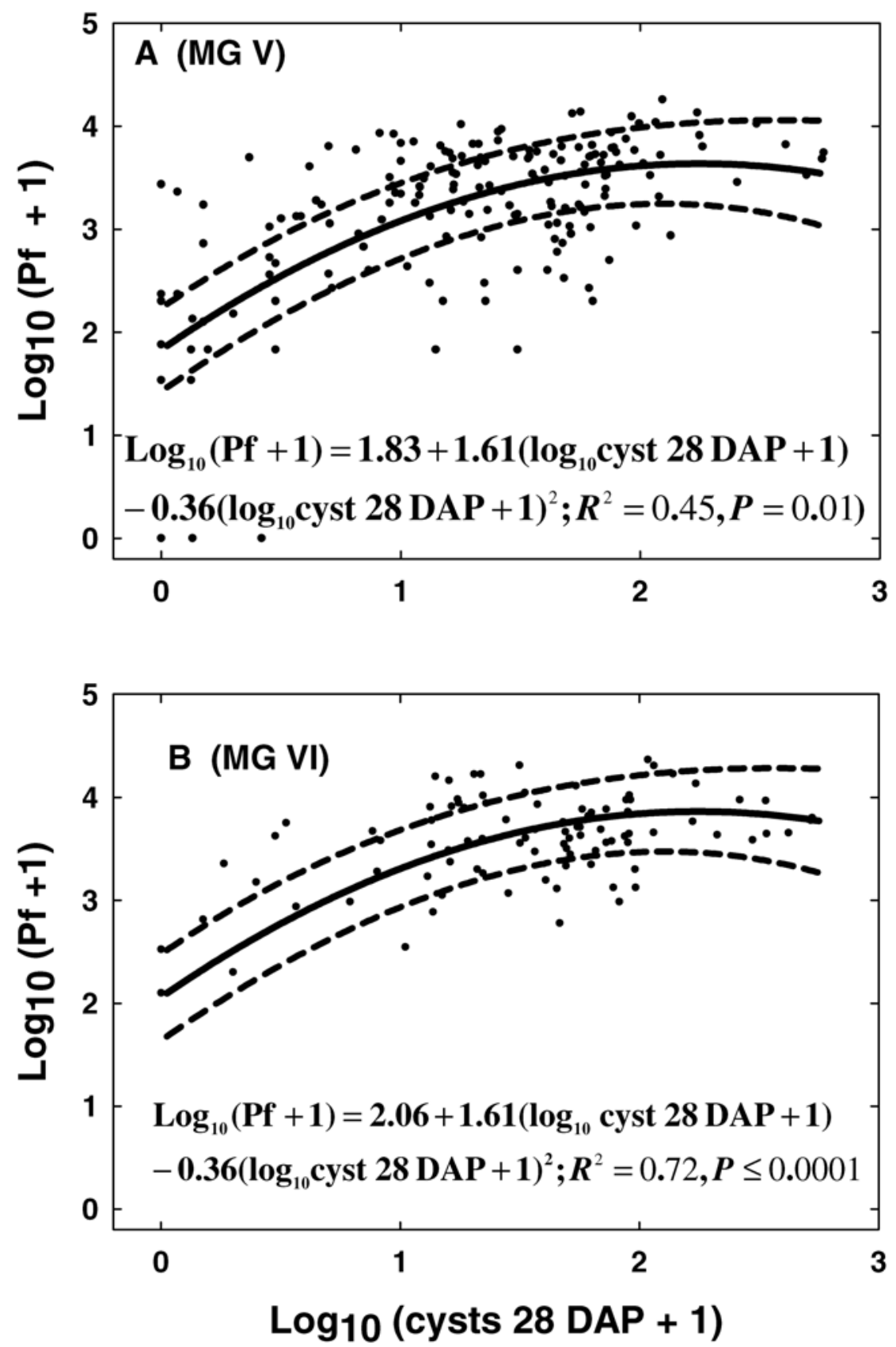

Fig. 2. Influence of the number of Heterodera glycines cysts per three plants at 28 days after planting (DAP) on final egg population density (Pf) of $H$. glycines per $500 \mathrm{~cm}^{3}$ of soil. Each data point is the mean of six observations per cultivar at each location from 1992 to 1999. Solid line is predicted response and dotted lines are the approximate 99\% confidence intervals from the PROC MIXED procedure of SAS. Responses differed $(P \leq 0.0001)$ by maturity group $(\mathrm{MG})$; thus, data are reported separately for $\mathbf{A}, \mathrm{MG} \mathrm{V}$ and $\mathbf{B}, \mathrm{MG}$ VI. $R^{2}$ value is for regression analysis, including both MGs as qualitative variables. 
TN5-95, S57-11, S65-50, and S60-E4. Highly resistant, moderately resistant, and susceptible cultivars differed $(P \leq 0.02)$ in numbers of cysts 28 DAP. Highly resistant cultivars had lower $(P \leq 0.01)$ SCN numbers at harvest than moderately resistant or susceptible cultivars, but final egg density for moderately resistant cultivars did not differ from susceptible cultivars. Highly resistant cultivars had greater $(P \leq 0.01)$ yields than did moderately resistant or susceptible cultivars at this site, and yield did not differ between moderately resistant and susceptible cultivars.

Reproduction of $\mathrm{H}$. glycines and impact on soybean yield in Chowan and Washington counties, 1998. Initial populations of SCN were relatively low at both locations in 1998. Hartwig, Delsoy 5710, Fowler, and Anand were highly resistant to the SCN race 4 population at the Chowan County site, whereas N93-54, A5343, A5348, DP 5554, S65-60, and x9855 were moderately resistant. Highly resistant, moderately resistant, and susceptible cultivars and lines differed in number of cysts 28 DAP $(P \leq 0.01)$ and final egg population density at soybean harvest $(P \leq 0.03)$. Soybean seed yield of highly resistant, moderately resistant, and susceptible cultivars and lines did not differ $(P \leq 0.10)$, because of the low initial inoculum density at this location.

Cultivars highly resistant to the race 4 population at the Washington, County site were Hartwig and Delsoy 5710, and moderately resistant cultivars included A5848, Fowler, S65-50, and TN5-92.
Highly resistant and moderately resistant cultivars did not differ in numbers of cysts at 28 DAP, but had lower $(P \leq 0.01)$ numbers of cysts than susceptible cultivars. Highly resistant cultivars had lower $(P \leq$ $0.05)$ numbers of SCN eggs at soybean harvest than susceptible cultivars, but egg numbers from plots with susceptible cultivars were not different from moderately resistant cultivars. Moderately resistant cultivars yielded more $(P \leq 0.10)$ than highly resistant and susceptible cultivars, and there was no difference $(P \leq 0.10)$ in yields of susceptible and highly resistant cultivars.

Reproduction of $\mathrm{H}$. glycines and impact on soybean yield in Currituck and Wilson counties, 1999. Hartwig, Delsoy 5710, and Fowler were highly resistant to the race 2 population at the Currituck County site, and no cultivars were moderately resistant. The number of cysts at 28 DAP and Pf was lower $(P \leq 0.01)$ on highly resistant cultivars than on susceptible cultivars. The three highly resistant cultivars yielded marginally more $(P \leq$ $0.06)$ than susceptible cultivars at this location. The higher yield of the resistant cultivars may be due to the very late planting date at this site. This was the only experiment in which MG V cultivars yielded more $(P \leq 0.02)$ than MG VI cultivars; all resistant cultivars were in MG V.

Four cultivars (Hartwig, Delsoy 5710, Fowler, and N96-223) were highly resistant and four were moderately resistant (Centennial, DP 3640, NK 57-11, and
TN5-95) to the race 5 population at the Wilson County site. Both highly and moderately resistant cultivars had lower $(P \leq$ $0.01)$ numbers of cysts on roots at $28 \mathrm{DAP}$ than susceptible cultivars. Highly resistant cultivars limited SCN final egg densities compared with moderately resistant cultivars and susceptible cultivars $(P \leq 0.01)$, but moderately resistant cultivars did not differ from susceptible cultivars. Highly resistant cultivars yielded more $(P \leq 0.01)$ than moderately resistant or susceptible cultivars, and the yield of moderately resistant and susceptible cultivars did not differ. Cultivars in MG VI yielded more than MG V cultivars at this location.

\section{DISCUSSION}

Significant reproduction of $H$. glycines occurred on most resistant and susceptible cultivars or lines, except those with resistance genes derived from PI 437654 (Hartwig, Delsoy 5710, S92-1603, Fowler, and Anand). The greater $\mathrm{Rf}$ values and final SCN density of MG VI cultivars compared with MG V cultivars was not surprising because the tendency for later-maturing cultivars to have higher final $H$. glycines population densities has been documented in other research $(16,17,24)$. Cultivars in both MG V and VI with resistance derived only from Peking often had higher Rf values than susceptible cultivars. The highest Rf values in MG VI cultivars, including Centennial (used in all experiments), A6711, DP726, DP3681, and DP6200RR $(\mathrm{Rf}=5.47,5.17,3.03,11.15$, and 9.44 respectively), generally were associated

Table 5. Yield (kg/ha) of soybean cultivars highly resistant (HR), moderately resistant (MR), or susceptible (S) to populations of Heterodera glycines, orthogonal contrasts (OC) for comparisons of yield by resistance class, and mean yield and OC for cultivars by maturity group (MG) at 14 sites in North Carolina from 1992 to 1995 and 1997 to 1999

\begin{tabular}{|c|c|c|c|c|c|c|c|c|c|c|c|c|c|}
\hline \multirow[b]{3}{*}{ Year, site } & \multirow[b]{3}{*}{ County } & \multirow{2}{*}{\multicolumn{3}{|c|}{ No. per class ${ }^{a}$}} & \multirow{2}{*}{\multicolumn{3}{|c|}{ Yield (kg/ha) }} & \multirow{2}{*}{\multicolumn{3}{|c|}{$\begin{array}{c}P \text { value } \\
O C \text { for yield }\end{array}$}} & \multirow{2}{*}{\multicolumn{2}{|c|}{ Yield mean (no.) ${ }^{b}$}} & \multirow{3}{*}{$\frac{\frac{P \text { value }}{\text { OC for MG }}}{\text { V vs VI }}$} \\
\hline & & & & & & & & & & & & & \\
\hline & & HR & MR & $\mathbf{S}$ & HR & MR & $\mathbf{S}$ & HR vs MR & MR vs S & HR vs $S$ & MG V & MG VI & \\
\hline \multicolumn{14}{|l|}{1992} \\
\hline 1 & Hoke & 2 & 4 & 6 & 863 & 744 & 545 & 0.14 & 0.09 & 0.01 & $657(6)$ & $791(6)$ & 0.01 \\
\hline 2 & Robeson & 1 & 0 & 11 & 497 & $\ldots$ & 249 & $\ldots$ & $\ldots$ & 0.01 & $278(6)$ & $260(6)$ & 0.64 \\
\hline \multicolumn{14}{|l|}{1993} \\
\hline 3 & Pitt & 1 & 2 & 14 & 940 & 1,298 & 993 & 0.07 & 0.05 & 0.78 & $1,057(11)$ & $1,148(6)$ & 0.10 \\
\hline 4 & Cumberland & 1 & 4 & 12 & 1,312 & 1,163 & 704 & 0.11 & 0.01 & 0.01 & 1,695 (11) & $1,890(6)$ & 0.06 \\
\hline 5 & Pasquotank & 1 & 1 & 15 & 2,184 & 2,054 & 2,151 & 0.88 & 0.81 & 0.16 & 1,961 (11) & $2,557(6)$ & 0.01 \\
\hline \multicolumn{14}{|l|}{1994} \\
\hline 6 & Tyrrel & 5 & 5 & 10 & 2,943 & 2,736 & 2,298 & 0.04 & 0.01 & 0.01 & $2,611(13)$ & $2,671(7)$ & 0.45 \\
\hline 7 & Martin & 1 & 4 & 15 & 2,047 & 1,408 & 1,538 & 0.01 & 0.19 & 0.01 & $1,405(13)$ & $1,727(7)$ & 0.01 \\
\hline \multicolumn{14}{|l|}{1995} \\
\hline 8 & Washington & 2 & 1 & 19 & 2,624 & 2,429 & 2,586 & 0.48 & 0.50 & 0.34 (13) & $2,577(13)$ & $2,587(9)$ & 0.93 \\
\hline \multicolumn{14}{|l|}{1997} \\
\hline 9 & Johnston & 6 & 7 & 9 & 2,180 & 1,750 & 1,747 & 0.01 & 0.98 & 0.01 & $1,654(16)$ & $2,323(6)$ & 0.01 \\
\hline 10 & Washington & 7 & 10 & 5 & 2,033 & 1,803 & 1,425 & 0.01 & 0.32 & 0.01 & $1,841(16)$ & $1,887(6)$ & 0.48 \\
\hline \multicolumn{14}{|l|}{1998} \\
\hline 11 & Chowan & 4 & 6 & 12 & 3,112 & 2,770 & 2,607 & 0.53 & 0.49 & 0.15 & $2,759(16)$ & $2,702(6)$ & 0.75 \\
\hline 12 & Washington & 2 & 4 & 16 & 1,733 & 1,975 & 1,788 & 0.07 & 0.08 & 0.70 & $1,795(16)$ & $1,958(6)$ & 0.15 \\
\hline \multicolumn{14}{|l|}{1999} \\
\hline 13 & Wilson & 4 & 4 & 10 & 1,907 & 1,631 & 1,533 & 0.01 & 0.25 & 0.01 & $1,588(12)$ & $1,739(6)$ & 0.02 \\
\hline 14 & Currituck & 3 & 0 & 15 & 1,228 & $\ldots$ & 1,150 & $\ldots$ & $\ldots$ & 0.06 & $1,136(12)$ & $1,031(6)$ & 0.02 \\
\hline
\end{tabular}

a Number of cultivars in class. Density classes are based on cyst numbers at 28 days after planting (DAP); resistance rating is based on (number of cysts on roots of plants $28 \mathrm{DAP} /$ number of cysts on susceptible cultivars $28 \mathrm{DAP}) \times 100$. Highly resistant (HR) is defined as $<10$ and moderately resistant as $>10$ and $<30$ (27).

${ }^{\mathrm{b}}$ Number in parenthesis is number of cultivars in MG. 
with defeated resistance genes derived from Peking. Higher levels of reproduction on cultivars with defeated resistance has been demonstrated by other researchers (12). Although cultivars with resistance derived from Peking and PI 88788 (resistance to races 3,9 , or 14 ) were highly or moderately resistant at some locations, some $H$. glycines reproduction generally occurred on these, and final $H$. glycines population densities frequently were equal to or greater than that on susceptible cultivars.

Reproduction of $H$. glycines based on the number of cysts 28 DAP or final population density of $H$. glycines on Delsoy 5710 did not differ from Hartwig in any of the five experiments where both were tested. These data indicate that Delsoy 5710 has the same compliment of SCNresistant genes as Hartwig. Fowler, which is derived from Hartwig, was highly resistant at three of the four sites in which it was tested, but was only moderately resistant at one site. Anand, which also is derived from Hartwig, was highly resistant at one site tested but not at a second site. The cultivars with resistance from PI 90763 (Cordell, TN5-92, and NK S61-89) were moderately resistant to populations in many of the fields where they were tested. The most extensively tested of the PI 90763-derived cultivars, TN5-92, was either highly or moderately resistant to $H$. glycines in 7 of 10 fields in which it was tested.

Most SCN-resistant cultivars are marketed as resistant to race 3 ; race 3 and 14; race 3 and 9 ; or races 3,9 , and 14 . Although the majority of the cultivars or lines evaluated in this research were derived from PI 88788, this resistance generally was not effective in minimizing $H$. glycines reproduction in North Carolina production fields. Only highly resistant cultivars such as Hartwig, Delsoy 5710, Fowler, and possibly Anand will accomplish the dual requirements for the use of a resistant cultivar: acceptable yield in the presence of SCN, and suppression or reduction in levels of SCN such that a susceptible crop can be included in the rotation. Unfortunately, Hartwig and Delsoy 5710 have not been widely accepted by growers because of limited yield potential (14). Fowler and Anand have better yield, but currently are little used because they are not glyphosate resistant (E. J. Dunphy personal communication). Additionally, because Anand and Fowler do not include the full compliment of resistance genes present in Hartwig, the durability of these resistant cultivars may be limited $(1,5,38)$.

Cultivars in MG VI yielded more $(P \leq$ $0.10)$ than MG V cultivars at 7 of the 14 locations used in this research, whereas MG V cultivars yielded more than MG VI cultivars only in 1999 at the Currituck County site. Nevertheless, MG V cultivars with resistance derived from PI 437654
(Delsoy 5710, Hartwig, Anand, and Fowler) all had relative yields of 1.00 or greater. Cultivars with resistance derived from PI 90763 (Cordell, TN5-92, and S6189) had relative yields less than 1 except that the relative yield of TN5-92 was equal to 1 .

There was considerable variation in the ability of SCN populations to parasitize cultivars with resistance derived from Peking and PI 88788. At several sites where the population was categorized as race 2 , 4 , or 5 , some cultivars purportedly resistant to races 3,9 , or 14 were moderately to highly resistant, whereas other cultivars with the same putative resistance were susceptible. These data indicate that different genes for resistance may be present in various cultivars derived from PI 88788 and Peking. Some discrepancies in cultivar resistance probably are related to differences in populations used in screening resistant cultivars. As a result of founder effects and genetic drift in greenhousemaintained populations, considerable variation in the virulence of greenhouse populations may occur. A new system for classification of $H$. glycines populations has been proposed, and may rectify this situation (20). The proposed system, however, still relies on the use of a series of plant introductions to delineate "Hetero-
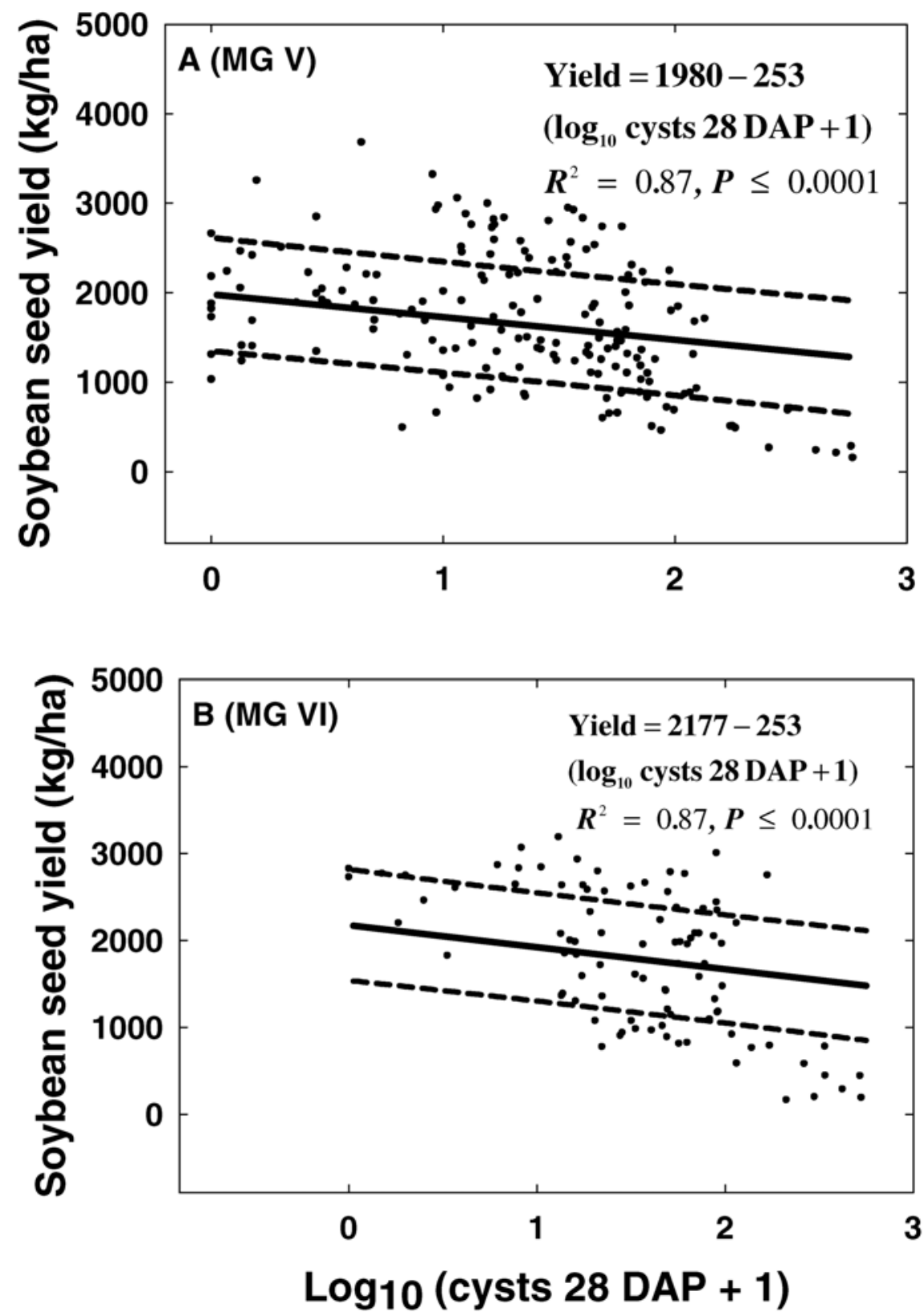

Fig. 3. Influence Heterodera glycines cysts per three plants (transformed $\log _{10}$ [mean preplant population density for the field $(\mathrm{Pi})+1])$ at 28 days after planting (DAP) on soybean seed yield. Each data point is the mean of four to six observations per cultivar at each location from 1992 to 1999 . Solid line is predicted response and dotted lines are the $99 \%$ confidence level. Responses differed $(P \leq 0.0001)$ by maturity group (MG); thus, data are reported separately for $\mathbf{A}$, MG V and $\mathbf{B}$, MG VI. $R^{2}$ value is for regression analysis, including both MGs as qualitative variables. 
dera glycines (HG) type". The HG type may not adequately discriminate between the ability of diverse $\mathrm{SCN}$ populations to reproduce on resistant cultivars derived from several resistant sources or that may not contain all genes for resistance contained in the parent PI.

The research in this article contrasts greatly from research conducted in Minnesota (8), where the majority of the cultivars were resistant to SCN field populations. There was an obvious advantage to using resistant cultivars in Minnesota, whereas the diversity of SCN populations in North Carolina indicates that the use of resistant cultivars is of minimal value except where the race has been identified and highly resistant cultivars with resistance derived from sources other than PI 88788 and Peking are available. A recent study conducted in Missouri concluded that most populations of SCN in that state were able to reproduce on PI 88788 and Peking (21). There is a continuing need to introgress host-plant resistance genes from diverse sources into productive soybean cultivars.

Schmitt and Ferris (26) proposed that field-specific probes or bioassays of soil be conducted to calibrate damage functions. Potentially, this proposal could be expanded to include the use of different resistant cultivars. The current research shows that the number of cysts at 28 DAP is a good field-specific predictor of soybean yield and subsequent SCN reproduction. The number of cysts at 28 DAP was a better indicator of yield and SCN Pf than $\mathrm{Pi}$, which is consistent with the fact that cultivars varied in their relative level of resistance to different populations of $H$. glycines. Thus, a quantitative model incorporating the relative amount of resistance to a given population could be combined with the initial population density for improved accuracy in predicting yield losses to SCN. Possibly, the results of greenhouse bioassays would be a better predictor of soybean yield potential in the presence of this pathogen, since they would integrate genetic, edaphic, other biologic (i.e., soil suppressiveness), and population density as factors affecting productivity. This information could be used to better deploy additional management tactics as required.

\section{ACKNOWLEDGMENTS}

I thank cooperators T. Powers, A. Gibson, W. Buck, W. Moore, G. Allen, J. Parker, C. Sawyer, E. Davenport, and D. Hinant; North Carolina Cooperative Extension Agents D. Baker, F. Oneal, E. Davis, R. Morris, P. Rowan, J. M. Williams, F. Winslow, N. Harrel, and T. Gandy; J. A. Phillips for technical support; K. M. Parker, K. R. Barker, E. J. Dunphy, and E. L. Davis for helpful suggestions in the revision and editing of this manuscript; M. L. Gumpertz of the Department of Statistics at North Carolina State University for valuable assistance in the statistical analysis of the data; and M. Shier of the University of Illinois Cooperative extension, G. Shannon of the UMC Delta Center, Portageville, MO, and E. J. Dunphy of North Carolina State University for valuable assistance in identifying the sources of resistance for many cultivars.

\section{LITERATURE CITED}

1. Anand, S. C. 1992. Registration of 'Hartwig' soybean. Crop Sci. 32:1069-1070.

2. Anand, S. C. 2000. Registration of 'Delsoy 5710' soybean. Crop Sci. 40:295-296.

3. Anand, S. C., Koenning, S. R., and Sharma, S. B. 1995. Performance of blends of soybean cyst nematode resistant and susceptible soybean cultivars. Crop Sci. 35:524-528.

4. Anand, S. C., Koenning, S. R., and Sharma, S. B. 1995. Effect of temporal deployment of different sources of resistance to soybean cyst nematode. J. Prod. Agric. 8:119-123

5. Anand, S. C., Newman, T., Fisher, J. 2001. Registration of 'Anand' soybean. Crop Sci. 41:919.

6. Bradley, E. B., and Duffy, M. 1982. The value of plant resistance to soybean cyst nematodes; a case study of Forest soybeans. U.S. Dep. Agric. Econ. Res. Serv. Nat. Res. Econ. Div.

7. Byrd, D. W., Jr., Barker, K. R., Ferris, H., Nusbaum, C. J., Griffin, W. E., Small, R. J., and Stone, C. A. 1976. Two semiautomatic elutriators for extracting nematodes and certain fungi from soil. J. Nematol. 8:206-212.

8. Chen, S. Y., Porter, P. M., Orf, J. H., Reese, C.D., Stienstra, W. C., Young, N. D., Walgenbach, D. D., Schaus, P. J., Arlt, T. J., and Breitenbach, F. R. 2001. Soybean cyst nematode population development and associated soybean yields of resistant and susceptible cultivars in Minnesota. Plant Dis. 85:760-766.

9. Davis, E. L. Koenning, S. R., Burton, J. W., and Barker, K. R. 1996. Greenhouse evaluation of selected soybean germplasm for resistance to North Carolina populations of Heterodera glycines, Rotylenchulus reniformis, and Meloidogyne species. Suppl. J. Nematol. 28:590-598.

10. Dong, K., Barker, K. R., and Opperman, C. H. 1997. Genetics of soybean-Heterodera glycines interactions. J. Nematol. 29:509-522.

11. Francl, L. J., and Dropkin, V. H. 1986. Heterodera glycines population dynamics and relation of initial population to soybean yield. Plant Dis. 70:791-795.

12. Francl, L. J., and Wrather, J. A. 1987. Effect of rotating 'Forrest' and 'Bedford' soybean on yield and soybean cyst nematode population dynamics. Crop Sci. 27:565-568.

13. Jenkins, W. R. 1964. A rapid centrifugalflotation technique for separating nematodes from soil. Plant Dis. Rep. 48:692.

14. Koenning, S. R. 2000. Density-dependent yield of Heterodera glycines-resistant- and susceptible-cultivars. Suppl. J. Nematol. 32:502-507.

15. Koenning, S. R., and Barker, K. R. 1998. Survey of Heterodera glycines races and other plant-parasitic nematodes on soybean in North Carolina. Suppl. J. Nematol. 30:569-576.

16. Koenning, S. R., Schmitt, D. P., and Barker, K. R. 1993. Effects of cropping systems on population density of Heterodera glycines and associated soybean yield. Plant Dis. 77:780786.

17. Koenning, S. R., Schmitt, D. P., and Barker, K. R. 1996. Soybean maturity group and planting date effects on seed yield and population densities of Heterodera glycines. Fundam. Appl. Nematol. 19:135-142.

18. Koenning, S. R., Schmitt, D. P., Barker, K. R., and Gumpertz. 1995. Rotation and tillage system effects on Heterodera glycines population densities and soybean yield. Plant Dis. 79:282-286.
19. MacGuidwin, A. E., Grau, C. R., and Oplinger, E. S. 1995. Impact of planting 'Bell', a soybean cultivar resistant to Heterodera glycines, in Wisconsin. J. Nematol. 27:78-85.

20. Niblack, T. L., Arelli, P. R., Noel, G. R., Opperman, C. H., Orf, J. H., Schmitt, D. P., Shannon, J. G., and Tylka, G. L. 2002. A revised classification scheme for genetically diverse populations of Heterodera glycines. J. Nematol. 34:279-288.

21. Niblack, T. L., Wrather, J. A., Heinz, R. D., and Donald, P. A. 2003. Distribution and virulence phenotypes of Heterodera glycines in Missouri. Plant Dis. 87:929-932.

22. Riggs, R. D., and Schmitt, D. P. 1988. Complete characterization of the race scheme for Heterodera glycines. J. Nematol. 20:392-395.

23. Roberts, P. A. 2002. Concepts and consequences of resistance. Pages 23-41. in: Plant Resistance to Parasitic Nematodes. J. L. Starr, R. Cook, and J. Bridge, eds. CABI, Wallingford, UK and New York.

24. Schmitt, D. P. 1991. Management of Heterodera glycines by cropping and cultural practices. J. Nematol. 23:348-352.

25. Schmitt, D. P., and Barker, K. R. 1987. Incidence of plant-parasitic nematodes in the coastal plain of North Carolina. Plant Dis. 72:107-110.

26. Schmitt, D. P., and Ferris, H., 1998. Pathogenicity and damage levels. Pages 239-265. in The Cyst Nematodes. S. B. Sharma, ed. Chapman and Hall, London.

27. Schmitt, D. P., and Shannon, G. 1992. Differentiating soybean responses to Heteroder glycines races. Crop Sci. 32:275-277.

28. Wang, J., Niblack, T. L., Tremain, J. W. Wiebold, W. J., Tylka, G. L. Marett, C. C. Noel, G. R., Myers, O., and Schmidt, M. W 2003. Soybean cyst nematode reduces soybean yield without causing obvious symptoms. Plant Dis. 87:623-628.

29. Wrather, J. A., Anderson, T. R., Arsyad, D. M. Tan, Y., Ploper, L. D., Porta-Puglia, A., Ram, H. H., and Yorinori, J. T. 2001. Soybean disease loss estimates for the top 10 soybean producing countries in 1998. Can. J. Plant Pathol. 23:115-121.

30. Young, L. D. 1984. Effects of continuous culture of resistant soybean cultivars on soybean cyst nematode reproduction. Plant Dis. 68:237-239.

31. Young, L. D. 1992. Problems and strategies associated with long-term use of nematode resistant cultivars. J. Nematol. 24:228-233.

32. Young, L. D. 1994. Changes in reproduction of a Heterodera glycines race 5 isolate cultured on 'Cordell' and 'Bedford' soybean. Suppl. J. Nematol. 26:653-655.

33. Young, L. D. 1994. Changes in the Heterodera glycines female index as affected by ten-year cropping sequences. J. Nematol. 26:505-510.

34. Young, L. D. 1996. Yield loss in soybean caused by Heterodera glycines. Suppl. J. Nematol. 28:604-607.

35. Young, L. D. 1998. Influence of soybean cropping sequences on seed yield and female index of the soybean cyst nematode. Plant Dis. 82:615-619.

36. Young, L. D. 1998. Heterodera glycines populations selected for reproduction on Hartwig soybean. (Abstr.) J. Nematol. 30:523.

37. Young, L. D. 1998. Managing soybean resistance to Heterodera glycines. Suppl. J. Nematol. 30:525-529.

38. Young, L. D. 2001. Registration of 'Fowler' soybean. Crop Sci. 41:257.

39. Young, L. D., and Hartwig, E. E. 1988. Selection pressure on soybean cyst nematode from soybean cropping sequences. Crop Sci. 28:845-847. 